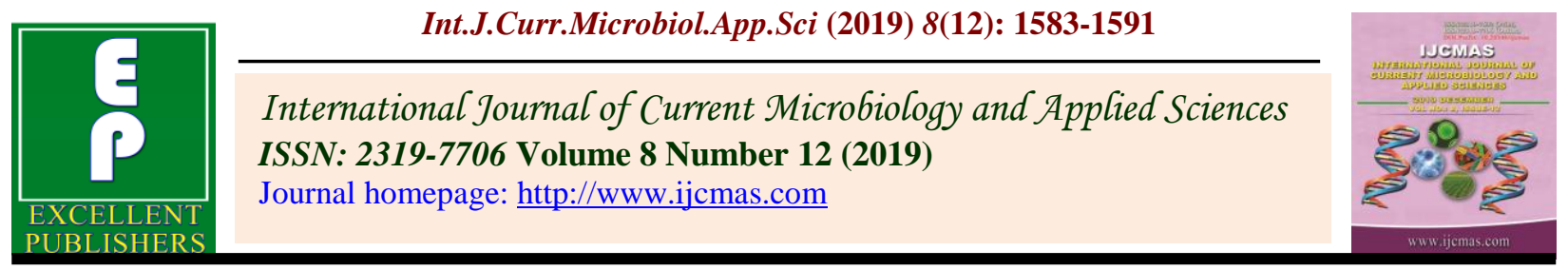

Original Research Article

https://doi.org/10.20546/ijcmas.2019.812.190

\title{
Market Integration of Major Maize Markets in Telangana State
}

\author{
Bandi Srikanth*, K. V. Deshmukh and S. S. More \\ Department of Agricultural Economics, College of Agriculture, Vasantrao Naik Marthwada \\ Krishi Vidyapeeth, Parbhani, Maharastra, India \\ *Corresponding author
}

\begin{tabular}{|l|}
\hline K e y w o r d s \\
Market integration, \\
Augmented Dickey- \\
Fuller, Co- \\
integration, Vector \\
error correction, \\
Prices and arrivals
\end{tabular}

\section{A B S T R A C T}

Market integration of agricultural products gained importance in developing countries due to its potential application to develop the national economy. The analysis of prices and market arrivals over time is important to know the fluctuations in them and it also helps to formulate appropriate ways and means for reducing price fluctuations of agricultural commodities. The present study was carried out by employing the integration of maize among major markets different tests, namely, Augmented Dickey-Fuller (ADF) unit root test, Johansen co-integration test, Granger causality test and Vector error correction method were carried out. The selections of the markets were based on the maximum quantity of arrivals of maize among the markets of Telangana state. The results of the study confirmed that markets are having long run equilibrium relationship and major markets of maize in Telangana state are integrated. All the three maize markets are highly co-integrated may be because of better marketing infrastructure, existence of cooperatives, easy flow of market information. High magnitude of speed of error correction indicates that markets are efficient in transmitting price signals.

\section{Introduction}

Agriculture is an important sector to fuel in economic growth and it needs to be made more attractive. By creating necessary framework for strengthening the entire agriculture value chain, the Government of India will not only help improve socioeconomic condition of the nation's farmers, but will also enable Indian agriculture to become economically profitable eventually leading to more inclusive development. Enabling policies for access to inputs, credit, markets and innovations will result in increased productivity, profitability and growth. Further with changes in production scenario it is also necessary to have effective agricultural marketing reforms to ensure that the farming is remunerative. For the Indian farmers to remain competitive, both in the 
domestic and international markets, Agriculture marketing services will have to be strengthened.

Agricultural prices play a key role in the national economy, which affects the production decisions of the farmers and their incomes. The analysis of prices and market arrivals over time is important to know the fluctuations in them and it also helps to formulate appropriate ways and means for reducing price fluctuations of agricultural commodities.

Market integration of agricultural products gained importance in developing countries due to its potential application to develop the national economy. Market integration is an important determinant of responsiveness and behavior of the markets needed to formulate price policies for providing infrastructure and information regulatory services to avoid market exploitation. The basic idea behind the measurement of market integration is to understand the interaction among prices in spatially separated markets (Goletti and Babu, 1994). The issue of market integration lies at the heart of many contemporary debates concerning market liberalization, price policy, and government reforms in developing countries. Spatial market integration refers to co-movement of prices and more generally, to the smooth transmission of price signals and information across spatially separated markets (Goletti, Ahmed and Farid, 1995). Two markets are co-integrated if prices in one market adjust to the price shocks in the other market. In association with market integration, the degree of price transmission may affect the speed of the trader's response to moving food to deficit areas. Hence, the development of an efficient marketing system is essential in the allocation of a scarce resource for the production and distribution of commodities among consumers (Acharya and Agarwal, 2011) and ensures stable and remunerative incomes to farmers (Ikudayisi and Salman, 2014). Thus the study of the agricultural market integration system helps to increase the profits to the producer and benefits the consumer which ultimately leads to the overall economic development.

This kind of study helps the farming community to know the remunerative prices for their harvest and also widens the market for their produce. Hence, market integration is a powerful tool, which alters the decision of the producers and also the consumers.

\section{Materials and Methods}

The newly formed Telangana state was purposively selected for the present study. In the view of specific objective for market integration, three major markets were selected. This study was based on secondary data and the data was collected from the AGMARK.NET. The selection of the markets was based on the maximum quantity of arrivals of maize among the markets of Telangana state. So, the selected markets were Mahabubnagar, Medak, and Karimnagar respectively.

\section{Market integration}

\section{Stationarity and volatility in prices of maize of selected markets of Telangana state}

\section{Testing of stationarity in price series of maize crop}

Before analyzing any time series data testing for stationarity is pre-requisite. The stationarity of time series data on maize prices was tested by applying the Augmented Dickey-Fuller test (ADF). The ADF test is the test for the unit root in a time series sample. A stationary series is one whose parameters are independent of time, exhibiting constant mean and variance and having autocorrelations that 
are invariant through time. If the series is found to be non-stationary, the first differences of the series are tested for stationary. The number of times (d) a series is differenced to make it stationary is referred to as the order of integration, $\mathrm{I}(\mathrm{d})$

ADF unit root test is based on the following three regression forms

Without constant and trends $\Delta \mathrm{Y}_{\mathrm{t}}=\delta \mathrm{Y}_{\mathrm{t}-1}+\mathrm{u}_{\mathrm{t}}$

With constant $\Delta \mathrm{Y}_{\mathrm{t}}=\alpha+\beta \mathrm{T}+\Delta \mathrm{Y}_{\mathrm{t}-1}+\mathrm{u}_{\mathrm{t}}$

With constant and trend

The hypothesis is: Ho: $\delta=0$ (unit root)

$\mathrm{H}_{1}: \delta \neq 0$

If $t^{*}>A D F$ critical value then accept the Null hypothesis, i.e. unit root exists and

If $t^{*}<\mathrm{ADF}$ critical value then reject the Null hypothesis, i.e. unit root does not exist.

\section{Co-integration among selected markets of Maize in Telangana region}

Johansen's Multiple Co-integration test was employed to determine the long-run relationship between the price series of selected markets. The test shows whether the selected maize markets are integrated or not. Johansen (1988) has developed a multivariate system of equations approach, which allows for simultaneous adjustment of both or even more than two variables. The multivariate systems of equations approach are more efficient than single equation approach since it allows estimating the co-integration vector with smaller variance. The second advantage of the multivariate approach is that in the simultaneous estimation it is not necessary to presuppose heterogeneity of either of the variables.
The common methodology was used for testing market integration involves the estimation of the bivariate correlation coefficient ( $r$ ) between price changes in a different selected market (Acharya and Agarwal, 1994).

$\mathrm{r}=\frac{\sum\left(\mathrm{P}_{11}-\mathrm{P}_{1}\right)\left(\mathrm{P}_{21}-\mathrm{P}_{2}\right)}{\sqrt{\left(\sum\left(\mathrm{P}_{11}-\mathrm{P}_{1}\right)^{2}\left(\mathrm{P}_{21}-\mathrm{P}_{2}\right)^{2}\right)}}$

Where,

$\mathrm{r}=$ Simple correlation coefficient

$\mathrm{P}_{11}=$ Price of the commodity in the first market.

$\mathrm{P}_{21}=$ Price of the commodity in the second market.

$\mathrm{P}_{1}=$ Mean of prices in the first market.

$\mathrm{P}_{2}=$ Mean of the prices in the second market.

Causality/ co-movement of price signals between selected markets

The Granger causality test was applied to study the price integration and to know the direction of causation between the selected markets. It is named after the first causality tests performed by Clive Granger (1969). It analyses the extent to which the past variations of one variable explain (or precede) subsequent variations of the other. When a cointegration relationship is present for two variables, a Granger Causality Test can be used to analyze the direction of this comovement relationship. Granger causality tests come in pairs, testing weather variable $\mathrm{x}_{\mathrm{t}}$ Granger causes variable $y_{t}$ and vice versa. All permutations are possible:

Univariate Granger causality from $x_{t}$ to $y_{t}$ or from $y_{t}$ to $x_{t}$ 
Bivariate causality or absence of causality.

Formally, the Granger causality test analyses weather the unrestricted equation:

$\mathrm{y}_{\mathrm{t}}=\alpha_{0}+\sum \mathrm{T}_{\mathrm{i}}=1 \alpha_{1} \mathrm{i} \mathrm{y}_{\mathrm{t}-\mathrm{i}}+\sum \mathrm{T}_{\mathrm{j}}=1 \alpha_{2} \mathrm{i} \mathrm{x}_{\mathrm{t}-\mathrm{j}}+\varepsilon_{\mathrm{t}}$ with $0 \leq \mathrm{I}, \mathrm{j} \leq \mathrm{T}$

Yield better results than the restricted equation:

$\mathrm{y}_{\mathrm{t}}=\beta_{0}+\sum \mathrm{T}_{\mathrm{i}}=1 \beta_{1} \mathrm{i} \mathrm{y}_{\mathrm{t}-\mathrm{i}}+\varepsilon_{\mathrm{t}}$ with $\sum \mathrm{T}_{\mathrm{j}}=1 \alpha_{2} \mathrm{j} \mathrm{x}_{\mathrm{t}-\mathrm{j}}$ $=0$ (The Null hypothesis)

i.e. if $\mathrm{H}_{0}$, in which $\alpha_{21}=\alpha_{22}=\ldots .=\alpha_{2} \mathrm{~T}=0$, is rejected then one can state "variable $\mathrm{x}_{\mathrm{t}}$ Granger causes variable $\mathrm{y}_{\mathrm{t}}$ "

Theoretically, a variable is said to Granger cause another variable, if the current value is conditional on the past value.

\section{Short-run and long-run equilibrium behavior of Maize market prices}

Vector Error Correction Model (VECM) was used to test the short-run and long-run behavior of maize market prices. Even if one demonstrates market integration through cointegration, there should be disequilibrium in the short run i.e. price adjustment across markets may not happen instantaneously. It may take some time for the special price adjustments. The error correction model can incorporate such short-run and long-run changes in price movement. A generalized VECM formulation to understand both the short-run and long-run behavior of prices can be considered by first taking the autoregressive distributed lag (AdL). The generalized form of this equation for $\mathrm{k}$ lags and an intercept term is as follows:

$\Delta \mathrm{Y}_{\mathrm{t}}=\mathrm{a}_{00}+\sum \mathrm{a}_{\mathrm{i}} 1 \Delta \mathrm{x}_{\mathrm{t}-1}+\mathrm{m}_{0}\left[\mathrm{~m}_{1} \mathrm{x}_{\mathrm{t}-\mathrm{k}}-\mathrm{y}_{\mathrm{t}-\mathrm{k}}\right]+\varepsilon_{\mathrm{t}}$

Where,
$\mathrm{M}_{0}=\left(1-\mathrm{a}_{\mathrm{i}} 2\right)$

The parameter $m_{0}$ measures the rate of adjustment of the short-run deviations towards the long-run equilibrium. Theoretically, this parameter lies between 0 to 1 . The value 0 denotes no adjustment and 1 indicates an instantaneous adjustment. A value between 0 to 1 indicates that any deviations will have a gradual adjustment to the long-run equilibrium values.

\section{To study market integration in selected markets}

Market integration explains the relationship between two markets that are spatially separated. One of the important indicators of efficient functioning of market is that the markets should be spatially integrated. Integrated markets are those where the prices are determined independently. If the markets located at different places are not integrated, there will be wide differences among the prices in different markets which cannot be explained by transport costs.

In integrated markets, price of commodity is responsible to price changes of same quality product in other markets, as such price differences for particular variety of product in different markets of production, should not exceed the cost involved in the transportation and handling of the produce. In this section to analyze market integration some tests and models were employed. To check whether the prices are stationary in markets under study or not, the Augmented Dickey-Fuller (ADF) test was employed. To determine the long run relationship between the price series or to test whether the selected maize markets are integrated or not, the Johansen's multiple cointegration tests was employed. In order to know the direction of causation between the markets Granger Causality test was employed. To understand both the short run and long run 
behavior of prices, the Vector Error Correction model was employed. The results of the same are as follows.

\section{Correlation coefficient for prices of Maize at selected Markets in Telangana state}

The bivariate correlation coefficient among the price series of the selected market pairs in the state were reported in Table 1. The bivariate correlation coefficients were calculated using nominal price series for maize in major markets of Telangana state, the correlation coefficients ranges 0.937 to 0.9521 . The strong associations were observed for two market pairs namely Mahabubnagar Medak; Medak - Karimnagar. The weak association was observed for the market pairs Mahabubnagar - Medak.

From the table 1 results revealed that there is a high and positive significant relation between Mahabubnagar, Medak and Karimnagar districts

\section{Testing stationary in price series}

The Augmented Dickey Fuller (ADF) based unit root test is carried out to check the stationary of the time series price data from three representative maize markets. The test was applied for Mahabubnagar, Medak and Karimnagar markets during the period of 2003 to 2017 and the results are presented in Table 2.

From table 2 it is observed that, at level with lag one, the ADF values of Mahabubnagar (1.15), Medak (-1.25) and Karimnagar (-2.03) less than the critical value at one per cent $(1 \%)$ level of significance indicating the non existence of unit root implied that the price series of three markets namely Mahabubnagar, Medak and Karimnagar are non-stationary. After taking first difference with lag one, the Augmented Dickey- Fuller (ADF) values of
Mahabubnagar (-10.47), Medak(-17.11) and Karimnagar market (-12.93) are lower than that of the critical value at one per cent level i.e. this implied that the prices series become stationary at first difference level and are free from the consequence of unit root.

\section{Co integration among the prices of the commodity in different markets}

Johansen's Co-integration test for selected Maize markets for the long-run co-integration was performed. If two series are potentially co-integrated, at least one co-integration relationship exists. Co-integration may be affected by some facts, such as transportation cost, tariffs, and so on. The null hypothesis statement of existence of $r$ co-integrated relationship against the alternative hypothesis of $r+1$ co-integration relationship was tested. Johansen (1988) and Johansen and Juselius (1990) have given new technique for co integration for long run as well as short run relationships for multivariate equation.

Johansen's Multiple Co-integration test was employed to determine the long run relationship between the price series. The test shows whether the selected Maize markets are integrated or not. The results of co-integration test showed at least three co-integration equations at 5\% level of significance indicating that the selected Maize markets are having long run equilibrium relationship and there exists co-integration between them.

\section{Causality among prices}

In order to know the direction of causation between the markets Granger Causality test was employed. When a co-integration relationship is present for two variables, a Granger Causality Test (Granger, 1969) can be used to analyze the direction of this comovement relationship. Theoretically, a variable is said to Granger-cause another 
variable, if the current value is conditional on the past value.

Engle and Granger (1987) showed that if two series are individually I (1), and co-integrated, a causal relationship will exist in at least one direction. For two first order co-integrated vectors, two stages are needed to estimate error correction model. First, the pair-wise Granger Causality test approach is carried out to know how much of influence of market prices can be explained by past values of that market prices; then second, to see whether adding lagged values of another major market prices can improve the explanation of behaviour of prices in the previous price behaviour of another market. The Granger causality test was conducted to analyze the influence of one market on the prices of other markets.

The casual relationship between the prices series of selected maize markets were approached through Granger Causality technique. The results of the analysis showing the relationship between selected Mize markets are presented in Table 3. It was observed from Table 4 that there is unidirectional causality affected on Maize prices of Mahabubnagar - Karimnagar and Mahabubnagar - Medak - it indicates that Karimnagar prices are depending on Mahabubnagar prices and Medak prices depends on Mahabubnagar prices. There is bidirectional causality affected on Maize prices of Medak - Karimnagar - It indicates that Karimnagar and medak prices are depending up on each other.

\section{Lead/lag markets, distortions in the markets}

Since the Johansen's Multiple Co-integration test results showed that the selected maize markets have long run equilibrium relationship and there exists co-integration between them. Hence, the Vector Error Correction Model (VECM) was employed to know the speed of adjustments among the maize markets for short run and long run equilibrium. The results of VECM are presented in Table 5.

The estimates of Vector Error Correction Model revealed that Karimnagar market one month lag price is affecting current prices of Karimnagar, Mahaboobnagar, and Medak markets, Karimnagar market two month lag price is affecting current prices of Medak market. Mahaboobnagar market one month lag price is affecting current prices of Karimnagar and Medak markets. Medak market one month lag price is affecting current prices of Mahabubnagar markets.

The bivariate correlation coefficients were calculated using nominal price series for maize in major markets of Telangana state, the strong associations were observed for two market pairs namely Mahabubnagar - Medak; Medak - Karimnagar. The weak association was observed for the market pair of Mahabubnagar - Medak. The Johansen's multiple co-integration procedure was applied to study the integration between the markets. Trace and maximum Eigen value indicated the presence of at least two integration equations at 5 percent level of significance.

Hence it is concluded that markets are having long run equilibrium relationship. The granger causality result revealed that there is unidirectional causality affected on Maize prices of Mahabubnagar - Karimnagar and Mahabubnagar - Medak - it indicates that Karimnagar prices are depending on Mahabubnagar prices and Medak prices depends on Mahabubnagar prices. There is bidirectional causality affected on Maize prices of Medak - Karimnagar - It indicates that Karimnagar and medak prices are depending up on each other. Thus the results 
of the study confirmed that major markets of maize in Telangana are integrated. All the three maize markets are highly co-integrated may be because of better marketing infrastructure, existence of cooperatives, easy flow of market information. High magnitude of speed of error correction indicates that markets are efficient in transmitting price signals. It advocate that even though the markets are geographically distributed and spatially divided, spatial pricing correlation revealed that the prices are linked together indicating that all the maize markets are in the same economic conditions.

Table.1 Correlation coefficient of prices for selected maize markets in Telangana state

\begin{tabular}{|c|c|c|c|}
\hline Market & Mahabubnagar & Medak & Karimnagar \\
\hline Mahabubnagar & 1 & $0.9376^{* *}$ & $0.9487^{* *}$ \\
\hline Medak & & 1 & $0.9521^{* *}$ \\
\hline Karimnagar & & & 1 \\
\hline
\end{tabular}

Significant at $0.01 \%$ indicates ‘**’

Table.2 ADF test results of maize prices for selected markets

\begin{tabular}{|c|c|c|c|}
\hline Particulars & Mahabubnagar & Medak & Karimnagar \\
\hline Level(ADF) & -1.15 & -1.25 & -2.03 \\
& $(0.69)$ & $(0.65)$ & $(0.27)$ \\
\hline First difference & -10.47 & -17.11 & -12.93 \\
(ADF) & $(0.00)$ & $(0.00)$ & $(0.00)$ \\
\hline Critical value at & & & \\
$\mathbf{1 \%}$ & & 2.87 & \\
\hline $\mathbf{5 \%}$ & & 3.46 & \\
\hline
\end{tabular}

** Significant at 1 per cent level

Table.3 Results of Johansen's multiple co-integration test for maize prices

\begin{tabular}{|c|c|c|c|c|c|c|c|}
\hline No. of CE(s) & $\begin{array}{c}\text { Eigen } \\
\text { value }\end{array}$ & $\begin{array}{c}\text { Trace } \\
\text { Statistic }\end{array}$ & $\begin{array}{c}\text { Critical } \\
\text { Value } \\
\text { 0.05 }\end{array}$ & Prob.** & $\begin{array}{c}\text { Max } \\
\text { Eigen } \\
\text { Statistic }\end{array}$ & $\begin{array}{c}\text { Critical } \\
\text { Value }\end{array}$ & Prob.** \\
\hline None * & 0.377 & 203.299 & 29.797 & 0.0001 & 82.5570 & 21.1316 & 0.000 \\
\hline At most 1 * & 0.355 & 120.742 & 15.494 & 0.0001 & 76.5381 & 14.2646 & 0.000 \\
\hline At most 2 * & 0.224 & 44.204 & 3.841 & 0.0000 & 44.2040 & 3.84146 & 0.000 \\
\hline
\end{tabular}


Table.4 Testing for pair-wise Granger causality

\begin{tabular}{|c|c|c|c|l|}
\hline $\begin{array}{c}\text { Null Hypothesis: } \\
\text { Mahabubnagar does not granger cause }\end{array}$ & 177 & 15.1211 & 0.00 & \\
\hline $\begin{array}{c}\text { Karimnagar } \\
\text { Karimnagar does not granger cause } \\
\text { Mahabubnagar }\end{array}$ & & 0.13591 & 0.87 & \\
\hline Medak does not granger cause Karimnagar & 177 & 3.92693 & 0.04 & \\
\hline Karimnagar does not granger cause Medak & & 3.38852 & 0.04 & \\
\hline Medak does not granger cause Mahabubnagar & 177 & 0.23229 & 0.79 & \\
\hline Mahabubnagar does not granger cause Medak & & 10.3775 & 0.00 & $\longrightarrow$ \\
\hline
\end{tabular}

Table.5 Speed of adjustment as measured by the error correction term in VECM

\begin{tabular}{|c|c|c|c|}
\hline Error Correction & Karimnagar & Mahabubnagar & Medak \\
\hline \multirow[t]{3}{*}{ CointEq1 } & -0.281912 & -0.23145 & 0.204549 \\
\hline & $(-0.08242)$ & $(-0.07099)$ & $(-0.04942)$ \\
\hline & {$[-3.42051]$} & {$[-3.26047]$} & [4.13858] \\
\hline \multirow[t]{3}{*}{ Karimnagar(-1) } & -0.3345615 & 0.187109 & -0.13393 \\
\hline & $(-0.09330)$ & $(-0.08036)$ & $(-0.05595)$ \\
\hline & {$[-3.58663]$} & [2.32852] & {$[-2.39384]$} \\
\hline \multirow[t]{3}{*}{ Karimnagar(-2) } & -0.12547 & 0.12593 & -0.136284 \\
\hline & $(-0.07975)$ & $(-0.06869)$ & $(-0.04782)$ \\
\hline & {$[-1.57330]$} & [1.83336] & {$[-2.84966]$} \\
\hline \multirow[t]{3}{*}{ Mahabubnagar(-1) } & 0.571581 & -0.107982 & 0.171259 \\
\hline & $(-0.09261)$ & $(-0.07976)$ & $(-0.05554)$ \\
\hline & {$[6.17201]$} & [-1.35377] & [3.08373] \\
\hline \multirow[t]{3}{*}{ Mahabubnagar(-2) } & 0.256404 & -0.039002 & 0.055745 \\
\hline & $(-0.09821)$ & $(-0.08459)$ & $(-0.05889)$ \\
\hline & [2.59249] & {$[-0.46109]$} & [0.94653] \\
\hline \multirow[t]{3}{*}{ Medak(-1) } & -0.073616 & -0.273147 & -0.154829 \\
\hline & $(-0.14520)$ & $(-0.12506)$ & $(-0.08707)$ \\
\hline & {$[-0.50701]$} & {$[-2.18418]$} & {$[-1.77818]$} \\
\hline \multirow[t]{3}{*}{ Medak(-2) } & -0.06435 & -0.079253 & 0.001212 \\
\hline & $(-0.12701)$ & $(-0.1094)$ & $(-0.07617)$ \\
\hline & {$[-0.50663]$} & {$[-0.72444]$} & [0.01591] \\
\hline \multirow[t]{3}{*}{ C } & 3.232553 & 5.059656 & 4.913344 \\
\hline & $(-8.37005)$ & $(-7.20912)$ & $(-5.01941)$ \\
\hline & {$[0.38620]$} & [0.70184] & [0.97887] \\
\hline
\end{tabular}




\section{References}

Goletti, F., and Babu, S. 1994. Market Liberalization and Integration of Maize Markets in Malawi. Agricultural Economics, 11 (2/3), 311-24.

Goletti, F., Ahmed, R., and Farid, N. 1995. Structural Determinants of Market Integration: The Case of Rice Markets in Bangladesh. The Developing Economics, 33(2), 185-202.

Acharya, S.S. and Agrawal, N.L. 2011. Agricultural marketing in India. Oxford and IBH Publishing Co. Pvt. Ltd. New Delhi.

Acharya, S.S. and Agrawal, N.L. 1994. Agricultural Prices: Analysis and Policy. New Delhi: Oxford and IBH Publishing Co. Pvt. Ltd.

Ikudayisi AA and Salman KK. 2014. Spatial Integration of maize market in Nigeria- a vector Error Correction Mode, int'l J. food Agric. Econ.2(3):71-80.

Johansen, S. 1988. Statistical Analysis of Cointegration Vectors. Journal of Economic Dynamics and Control, 12(2-3): 231-254.

More, S. S. 1999. Economics of production and marketing of banana in Maharashtra state. M.Sc. (Agri.) Thesis, University of Agricultural Sciences, Dharwad.

Manohar, N.S., A.K. Dixit, and B.S. Reddy. 2012. Market integration and price behaviour in maize markets. Inian $J$. Agril. Mktg., 26(1): 123-129.

Sendhil R, Kar A, Mathur V C and Jha G K. 2013. Price discovery, transmission and volatility: Evidence from agricultural commodity futures. Agril Econ Res Rev 26(1): 41-54.

\section{How to cite this article:}

Bandi Srikanth, K. V. Deshmukh and More, S. S. 2019. Market Integration of Major Maize Markets in Telangana State. Int.J.Curr.Microbiol.App.Sci. 8(12): 1583-1591. doi: https://doi.org/10.20546/ijcmas.2019.812.190 